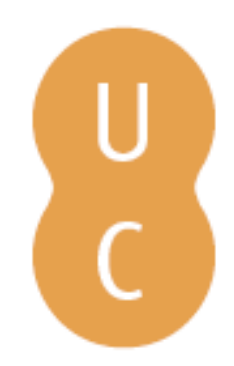

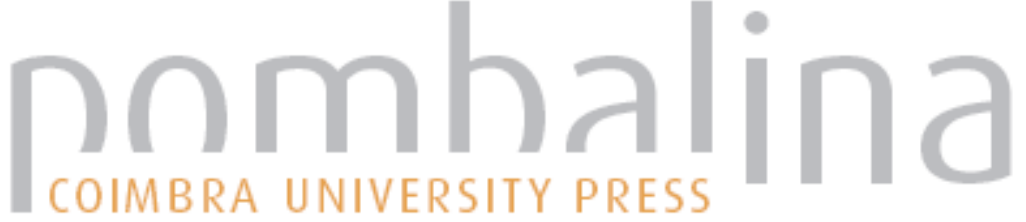

\section{Dirigismo cultural e formação das elites no Pombalismo}

\author{
Autor(es): $\quad$ Araújo, Ana Cristina
}

Publicado por: Imprensa da Universidade de Coimbra

URL

persistente:

URI:http://hdl.handle.net/10316.2/32746

DOI:

DOl:http://dx.doi.org/10.14195/978-989-26-0373-5_1

Accessed : $\quad$ 26-Apr-2023 12:03:19

A navegação consulta e descarregamento dos títulos inseridos nas Bibliotecas Digitais UC Digitalis, UC Pombalina e UC Impactum, pressupõem a aceitação plena e sem reservas dos Termos e Condições de Uso destas Bibliotecas Digitais, disponíveis em https://digitalis.uc.pt/pt-pt/termos.

Conforme exposto nos referidos Termos e Condições de Uso, o descarregamento de títulos de acesso restrito requer uma licença válida de autorização devendo o utilizador aceder ao(s) documento(s) a partir de um endereço de IP da instituição detentora da supramencionada licença.

Ao utilizador é apenas permitido o descarregamento para uso pessoal, pelo que o emprego do(s) título(s) descarregado(s) para outro fim, designadamente comercial, carece de autorização do respetivo autor ou editor da obra.

Na medida em que todas as obras da UC Digitalis se encontram protegidas pelo Código do Direito de Autor e Direitos Conexos e demais legislação aplicável, toda a cópia, parcial ou total, deste documento, nos casos em que é legalmente admitida, deverá conter ou fazer-se acompanhar por este aviso. 


\section{ANA CRISTINA ARAÚJO \\ Coordenação}

\section{O Marquês de Pombal e a Universidade}

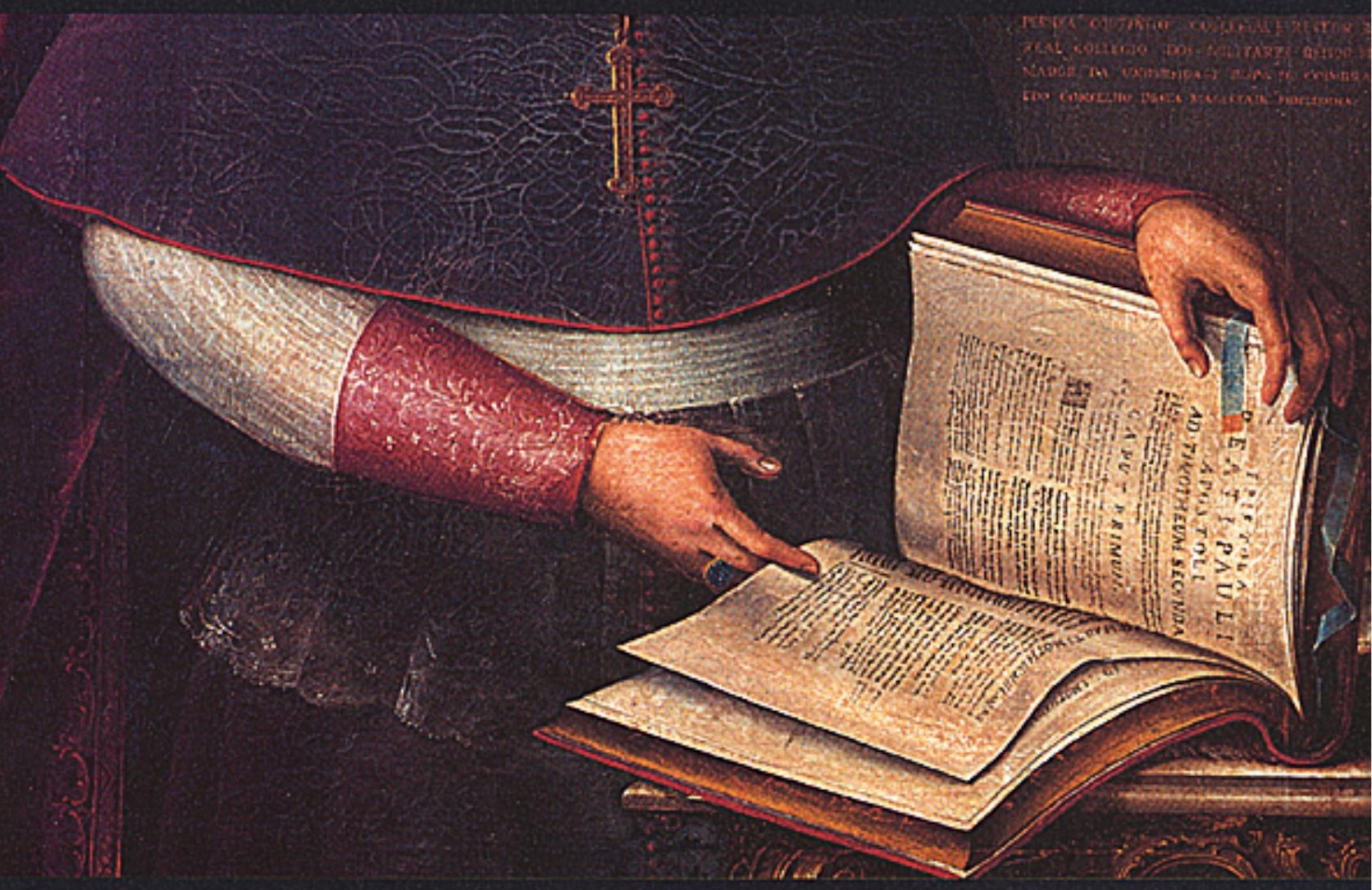

139. Coimbra - Imprensa da Universidade 
(Página deixada propositadamente em branco) 


\section{Dirigismo Cultural e Formação das Elites no Pombalismo}

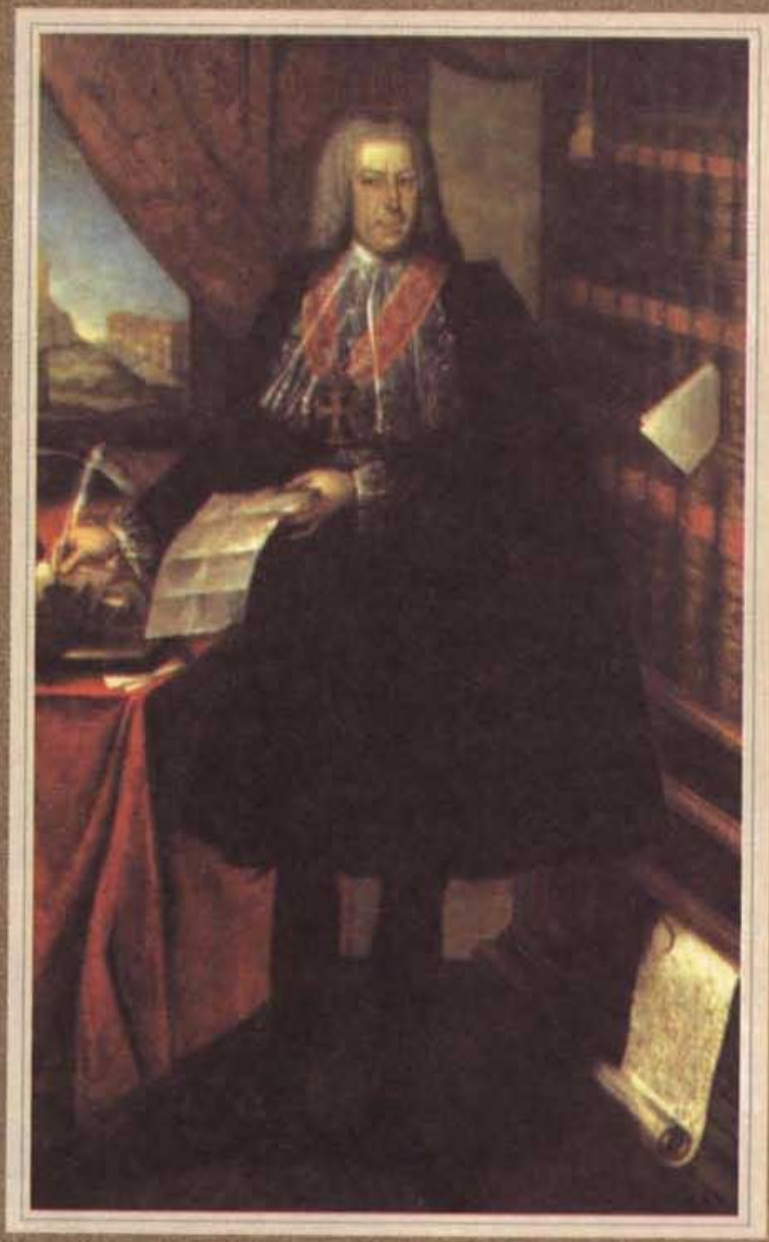


Retrato do Marquês de Pombal. Joana do Salitre (atrib.). Museu da Cidade de Lisboa foto: António Rafael, MCL 


\section{ana Cristina araujo*}

\section{DIRIGISMO CULTURAL E FORMAÇÃO DAS ELITES NO POMBALISMO}

É sob o signo da reforma intelectual e moral da sociedade, eixo de bem estar, progresso e felicidade, que o Marquês de Pombal, à semelhança de outros déspotas esclarecidos europeus, intenta secularizar as instituições de ensino, submetendo-as à tutela do Estado. A "necessidade pública" e a prática das "nações civilizadas", expressões constantes dos diplomas régios, reforçavam a ideia de que o Estado podia objectivamente beneficiar do influxo racional e crítico das ciências e das artes, colocando-as ao serviço da sociedade. A evolução dos diversos ramos do conhecimento mostrava que o "exame da Natureza, por meio da experiência e da exacta observação", era cada vez mais conduzido com "o apoio dos Principes: Sendo ensinada nas Universidades mais célebres da Europa: Illustrando todas as Sciencias que dela depend[ia]m: Aperfeiçoando as Artes Liberaes e mecanicas: E produzindo immensas utilidades em beneficio das Familias, e dos Estados" I.

Nas escolas reformadas devia haver, contudo, "menos cuidado em ilustrar o espírito dos estudantes com a luz das ciências; do que em formar os corações com a prática das virtudes" 2 . Compreende-se. A educação encarada como um dever público, destinava-se a instaurar a crença numa ordem univer-

- Faculdade de Letras da Universidade de Coimbra. Centro de História da Sociedade e da Cultura.

I Compêndio Histórico do Estado da Universidade de Coimbra no tempo da invasão dos denominados jesuitas e dos estrogos feitos nas sciencias e nos professores, e directores que a regiam pelas maquinações, e publicoçôes dos novos estatutos por elles fabricados, Lısboa, Regia Officina Typografica, I771, p. 336.

2 Franscisco de Lemos, Relaçāo Geral do Estado da Universidade desde o princípio da Nova Reformaçāo oté ao mês de Setembro de 1777. Coimbra. Biblioteca Geral da Universidade, 1980. p. 198. Este documento, redigido pelo reitor reformador da universidade, destinava-se a ser submetido à apreciação de D. Maria I. Foi pela primeira vez publicado, em I894, por Teófilo Braga. 
sal de valores que compatibilizasse o progresso do género humano, no respeito pela matriz cristã, com a finalidade técnica decorrente da utilidade social da ciência. Interpretando fielmente o alcance da obra pombalina. D. Francisco de Lemos diz que: "Faltar a qualquer destes objectos seria arruinar a Educação Nacional, a qual dev(ia) merecer atenção e vigilância dos soberanos, por ser o princípio e origem da Felicidade Pública das Monarquias" 3 . Pensada nestes termos, a educação cumpria uma função aglutinadora essencial. A cultura ao serviço do Estado reforçava o papel de sociabilização política da escola. O sonho de emancipação do homem, decorrente da filosofia racionalista e cientista do lluminismo, ligava-se ao mito do "monarca benfazejo", encarnado pelos mais representativos "déspotas esclarecidos" europeus: Frederico II. Catarina II, Maria Teresa de Áustria, José II, Carlos III e Stanislau da Polónia ${ }^{4}$. A conformação da lei às máximas do direito natural, realizada sob os auspícios de um poder soberano, aureolado pelas Luzes da Razão, conduziria à eliminação progressiva dos costumes contrários à harmonia e ao equilibrio da Humanidade. Este optimismo jurídico alicerçava a confiança na possibilidade de instauração, com base nas máximas do direito natural, da virtude e da felicidade geral. Todavia, no quadro da sociedade civil, a consumação hedonista da razão não dispensava a crença no poder regenerador da escola. De certo modo, ao legislador como ao pedagogo incumbia infundir as Luzes da Razão e criar as condições para que o ideal de perfectibilidade individual se articulasse com a marcha invariável do progresso colectivo. Por isso, D. Francisco de Lemos, reitor reformador da Universidade e activo colaborador de Pombal no planeamento do ensino público, não hesita em fazer da escola o fulcro da unidade moral da nação e do Estado a alavanca da renovação da Igreja.

${ }^{3}$ Francisco de Lemos, ob cit. p. 198. Braço direito de Sebastião losé de Carvalho e Melo para a reforma dos estudos. D. Francisco de Lemos de Faria Pereira Coutinho, natural do Rio de Janeiro. doutorou-se em Cânones em 1754. foi reitor do Colégio das Ordens Militares, juiz geral das três Ordens Militares, deputado da Inquisıção de Lisboa, deputado ordinário do Tribunal da Real Mesa Censória, desembargador da Casa da Suplicação, vigário capitular da diocese de Coimbra, de 1768 a 1770, bispo da diocese de Coimbra e reitor reformador da Universidade. Manuel Augusto Rodrigues. A Universıdade de Coimbra e os seus Reitores. Para uma História da instituição. Coimbra, Arquivo da Universidade de Coimbra, 1990, pp. 150-i62; Idem, D. Francisco de Lemos e o Cabido do Sé de Coimbra, sep. do Boletim do Arquivo da Universidade de Cormbra, vol. IX, 1986.

${ }_{4}$ Para uma compreensão global da tutela política sobre a educaçāo no século XVIII, veja-se Marina Roggero, "Éducation", in Vicenzo Ferrone e Daniel Roche (dir.), Le Monde des Lumières. Paris. Fayard. 1999, pp. 239-249. 


\section{Os limites de um projecto de Educação Nacional}

Retomando a filosofia inspiradora da reforma escolar pombalina verifica-se que, no quadro de uma administração controlada dos saberes, os ideais cristãos continuam a servir de sólidos alicerces a uma educação renovada e que os meios e dispositivos tendentes à formação da juventude são estańdardizados, de molde a proporcionar um padrão uniforme de conhecimentos a todos os alunos matriculados nas escolas oficiais. Globalmente, o projecto pombalino aponta para uma educação gratuita, ao nivel elementar, socialmente selectiva e culturalmente exclusiva. Estes postulados estão jả subjacentes à criação das escolas menores, cuja rede de implantação principia em 1759. com a substituição dos colégios jesuítas pelas primeiras classes reais de gramática latina, de grego, de retórica e de filosofia. Mas é com a carta de lei de 6 de Novembro de 1772, que institui e regulamenta os estabelecimentos oficiais de primeiras letras e de aritmética em todas as comarcas do reino. que eles verdadeiramente ganham expressão prática ${ }^{5}$. A organização vertical do edifício escolar acentua, portanto, o carácter elitista de um modelo de instrução que tem como zénite a reforma universitária de 1772, pensada em articulação com o ensino médio no que tange à habilitação às Faculdades e na forma como passam a ser encarados os estudos preparatórios 6 .

Em traços largos, as bases do sistema de ensino pombalino aproximam-se, quanto à sua justificação e finalidade, do programa que Louis René Caradeuc de la Chalotais enuncia no seu Essai d'Éducation Nationale (1763). O plano do pedagogo francês, apresentado igualmente como resposta à falência das escolas jesuítas, afastava as camadas populares da escola com - argumento de que "le bien de la societé demande que les connaissances du peuple ne s'étendent pas plus que ses ocupations" 7 . Este modo de pensar,

5 Vejam-se, por todos, Joaquim Ferreira Gomes, 0 Marquês de Pormbal e as reformas do ensino, $2^{\mathrm{a}}$ ed., Coimbra, INIC, 1989; e António Nóvoa, Le Temps des Professeurs, vol, I, Lisboa, INIC, 1987

6 Documentos da Reforma Pombalina, publicados por M. Lopes de Aimeida, Coimbra, Por Ordem da Universidade, 1937. vol. I. doc, XVI. pp. 16-18. Theophilo Braga, História da Uni. versidade de Coimbra nas suas relações com a instruç̧ão publica portugueza, t. III, Lisboa, Academia Real das Ciências, 1898.

7 Cit, in Jacques Marcadé. "Pombal et l'enseignement. quelques notes sur la reforme des estudos menores", Revisto de História das Ideias, O Marquês de Pombal e o seu Tempo, t. II. Coim. bra, 1982, p. 14. 
partilhado em França pela maioria dos filósofos das Luzes, de Voltaire a Mirabeau, encontra na Península Ibérica dois grandes defensores: Pablo de Olavide e Ribeiro Sanches. Em termos práticos, a mesma orientação inspira as políticas reformistas de D. José I e de Carlos 1118 .

Nos diversos graus de ensino, mas sobretudo na Universidade, passa a vigorar o método "sintético-demonstrativo" - só "por meio dele se pode adquirir hum conhecimento profundo e sólido das Sciencias" 9 . A defesa do método compreende todo o sistema educativo, uma vez que se reconhece que "quem desconhece o Methodo não pode ter ordem no Estudo" 10. Mas é em face dos novos caminhos abertos pelo conhecimento do mundo natural que mais se acentua a sua necessidade, dado que a experiência mostrava que "quem estuda sem ordem, adianta-se pouco na Estrada das Sciencias" II. Para evitar os erros resultantes da linguagem dos sentidos e das falsas ideias convertidas em "conhecimento médio", já em 1746 Vernei advogava que a experiência e a razão constitúam o fundamento de toda a verdade. E porque as "leis das ciências" requeriam um método seguro, "a principal operação livre da mente" deveria incidir sobre o "Raciocínio ou o Discurso". Boa ordem de raciocínio na formulação de hipóteses, na inferência dos resultados e clareza na formulação destes eram procedimentos indispensáveis para o estudo de qualquer matéria pois, como sublinhava Vernei, "o que importa é julgar primeiro bem e não se enganar nas premissas; porque só assim é que não se enganará na conclusão. [...] Para não nos enganarmos no método é necessário ter diante dos olhos que nós ignoramos a essência de todas as coisas" 12 .

As ideias-força das Luzes, filtradas por compromissos e mediações que visam o controlo do processo educativo têm ainda subentendida a ideia, cara ao empirismo, de que o indivíduo se apresenta, desde o seu nascimento,

8 Para Espanha veja-se, especialmente, Jean Sarrailh, L'Espagne Éclairée de la seconde moitié du XVlle siècle, Paris, Imprimerie Nationale, 1954.

9 Compendio Histórico do Estado da Universidade de Coimbro.... p. 245. A questão do método é aqui tratada no âmbito da doutrina das escolas jurídicas. Sobre o assunto veja-se. Mário Júlio de Almeida e Costa, "Debate jurídico e solução pombalina", in Brotéria, Cultura e informaçāo, vol. 1 15, ns 2,3,4, 1982, p. 162; Noutros parágragos do Compendio Histórico enunciam-se as vantagens, mas não as regras, dos procedimentos experimentais e crítico-dedutivos.

10 Compendio Histórico do Estado da Universidade de Coimbra.... p. 245.

11 Idem, ibidem.

12 Luís António Verney, Verdadeiro Método de Estudar, edição organizada por António Salgado Júnior, carta ortava, vol. III, Lisboa, Livraria Sá da Costa, 1950. pp. 101 e 105. 
como uma "tábua rasa", constituindo a infância o tempo, por excelência, da aprendizagem das mais importantes noções necessárias à vida. Esta concepção, tributária de John Locke é expressa, entre outros, por Martinho de Mendonça de Pina e Proença, nos Apontamentos para a educação de um menino nobre (1734) 13. A inequívoca projecção prática desta revolucionária premissa pedagógica, sendo correlata de uma visão reabilitante da infância nos escritos de outros pensadores que influenciaram, igualmente, o sentido das reformas pombalinas do ensino, apontava para a valorização das potencialidades educativas da escola na transmissão de conteúdos morais e intelectuais que subtraiam a experiência sensivel ao domínio da natureza e inscreviam o homem na matriz optimista de uma civilização votada ao progresso.

Ao justo princípio de que "a faculdade de pensar é livre no homem" 14. contrapunha-se a ideia de que a liberdade tinha como "limites" as máximas da "razão e da religião" 15 . Submetendo o múnus das verdades da fé ao culto da razão soberana, a filosofia cultural do pombalismo assimila o racionalismo crítico de base científica ao catolicismo, modernizando, ao mesmo tempo, a escola e a Igreja. Por isso, a mesma razão que julga e fulmina os jesuítas, trava os mais radicais anseios de renovação das Luzes, sancionando, em nome da "Suprema Jurisdição Temporal", a repressão de enciclopedistas, deístas e materialistas. $O$ papel proeminente que algumas figuras cimeiras da Igreja portuguesa tiveram na planificação das reformas da educação comprova que, neste domínio, o Marquês de Pombal, não descurando as orientaçōes filosóficas veiculadas por conselheiros mais distantes, toma como fio condutor da sua acção governativa o discurso regalista dos sectores ilustrados do clero.

Apesar dos mecanismos institucionais criados para que a difusão das Luzes não comprometesse a segurança do Estado, a crítica estendeu-se à política, sem renunciar à sua "pretensão apolítica - quer dizer racional, natural ou moral -, que the garantia a prerrogativa da verdade" ${ }^{16}$. Em nome do bem público, mas por uma via inversa àquela que o próprio Estado postulava.

13 Joaquim Ferreira Gomes. Martinho de Mendonça e a sua obra pedagógica (com a ediçāo crítica dos "Apontamentos para a educação de hum menino nobre"). Cormbra, Instituto de Estudos Filosóficos, Universidade de Cormbra, 1964.

14 Franscisco de Lemos, Relação Geral do Estado da Universidade (1777).... p. 213.

is idem, ibidem.

16 Reinhart Koselleck Crítca e Crise. Uma contribuição à patogênese do mundo burguês, Rio de Janeiro, Eduerj, 1999. p. 104. 
ou seja, a da identificação dos interesses superiores do Soberano e dos seus súbditos, acentuou-se a separação da instância judicativa da crítica face à competência política do Estado. $O$ critério diferenciador da razão ao transferir-se para o campo do julgamento moral, colocou a lei sob suspeição. Esta, entendida não ainda como expressão da vontade geral mas como produto da livre manifestação de interesses e aspirações individuais, deixara de corresponder aos valores e às necessidades da sociedade. Daí a afirmação de que a "igualdade entre todos os subditos" 17, firmada na imprescritível liberdade de pensamento, era, por natureza, incompatível com a "escravidão" que "faz perder aquella igualdade civil, [...] vinculo e força do Estado", e com a "intolerância" que "faz perder aquela humanidade, que he o dezejo de a conservar para imitar o Supremo Criador" 18. Para corrigir as deformidades introduzidas por regimes usurpadores dos direitos dos povos, Ribeiro Sanches concluía, portanto, que "as leis se devem mudar, tanto que mudão as circunstancias nas quaes se conserva o Estado Politico civil" 19.

Subordinada ao imperativo da secularização, a crítica liberta-se progressivamente do primado das instituições que a instauram, impondo-se de forma autónoma, contra a falta de tolerância e contra os entraves criados à livre circulação de ideias. No tempo de D. Maria I, Ribeiro dos Santos, que não nutria especial simpatia pelo "edificio ruinoso" da instrução pública acabado de erguer, reflectia, nestes termos, sobre o paradoxo que Pombal criara: "Este ministro quis um impossivel político; quis civilizar a Nação e ao mesmo tempo fazê-la escrava; quis espalhar a luz das ciências filosóficas e ao mesmo tempo elevar o poder real ao despotismo; inculcou muito o estudo do Direito Natural e das Gentes e do Direito Público Universal e Ihes erigiu cadeiras na Universidade; mas não via que dava luzes aos povos para conhecer por elas que o poder soberano era unicamente estabelecido para o bem comum da Nação e não do príncipe. e que tinha limites e balizas em que se devia conter" 20 .

17 Antonio Nunes Ribeiro Sanches, Contas sobre a Educaçāo da Mocidade, in Obros, vol. I Coimbra, Por ordem da Universidade, 1959, p. 219.

18 kdem, ibidem, p. 275.

19 Idem, ibidem, p. 276.

20 BNL. Ms 130, fl. 203, crt. in Hernâni Cidade, LLçōes de Culturo e Literatura Portuguesas, $2^{\circ}$ vol., Coimbra, Coimbra Editora, 1984, $7^{\circ}$ ed., pp. 225-226. Cf. Kenneth Maxwell, Pombal. Paradox of the Enlightenment. Cambridge. Cambdrige University Press, 1995, e José Estêves Pereira. O pensamento politico em Portugal no século XVIII, António Ribeiro dos Santos, Lisboa, IN-CM. 1983 
O paradoxo do lluminismo, extensível a todos os estados europeus em que vigorou o Absolutismo Esclarecido 21 , foi talvez levado às últimas consequências pelo regime pombalino, incapaz de resolver a contradição de base da sua política educativa: fazer da crítica o fundamento da modernidade e, sob os auspícios da ideia de progresso, manter amarrada a razão à tradição. E se, numa acepção mais lata, até mesmo o escopo dogmático da interpretação do direito - a lei de 18 de Agosto de 1769. conhecida pela designação de lei da Boa Razão - concilia a doutrina do direito natural e a norma ditada pela prática jurídica das nações mais civilizadas com a tradição ${ }^{22}$, faz todo o sentido que, no domínio cultural e educacional, a recta ratio jusnaturalista, convocada para fundamentar a limitação da liberdade dos súbditos e restringir a livre circulação das ideias, acabe por funcionar como garantia de ampliação irrrestrita da soberania régia.

Não pode contudo dizer-se que os mentores da política cultural pombalina desconhecessem os perigos ou os efeitos "perversos" das reformas que patrocinavam. Para calar aqueles que viam despontar o espírito da heresia no terreno em que frutificavam a ciência, a filosofia, o direito e a história, D. Francisco de Lemos condescendia: "muitas vezes a liberdade de opinar nas Ciências po(de) induzir os homens a alguns erros de Religião e de Política" - mas logo a seguir optava pelo mal menor - "no meio dos males quem pode duvidar que é menor este, que o estado consistente e inalterável de trevas, em que se põem as Nações por estarem presos os espíritos e privados do raciocínio que lhes é natural" 23.

\section{O Estado, a Igreja e a Escola}

Índice inequívoco da orientação ilustrada do governo pombalino, a reforma da "Educação Nacional", embora aberta a influências de tipo jansenista, filia-se directamente na corrente regalista que caracteriza o Absolutismo

21 Derek Beales, Joseph II in the Shadow of Maria Theresa, 1741-1780. Cambdrige. Cambdrige University Press, 1987, pp. 1-16.

22 Sobre a lei de 18 de Agosto de 1769, conhecida por Lei da Boa Razão, veja-se, especialmente, Mário Júlio de Almeıda Costa, "Debate jurídıco e soluçāo pombalina...". pp. 157-169; e Rui Marcos, A Legislação Pombalina. Alguns aspectos fundamentais, Coimbra, Sep, do vol. XXXIII do Suplemento oo Boletim da Faculdade de Direito. 1990. pp. 80-82.

23 Franscisco de Lemos, Relaçōo Geral do Estudo da Universidade (1777) .... p. 213. 
Esclarecido português ${ }^{24}$. Com o propósito de fortalecer a adesão integral dos súbditos à Coroa, D. José I, que na esfera temporal não reconhece a superioridade de Roma, sujeita os institutos religiosos e todos os organismos que tradicionalmente the eram adictos às leis da Monarquia. Para conservar a ordem pública e defender os sagrados princípios da religião, mantendo inviolável o primado da lei, o clero é chamado a contribuir para o bem público e para a felicidade geral. Nesta base, a subversão da disciplina interna da Igreja é pensada em função dos superiores interesses do Estado. Na prática, e no domínio que nos propomos analisar, o poder de jurisdição da Igreja diminui no que tange à censura e à educação, áreas em que as instituições eclesiásticas tinham um forte ascendente e em que o ancestral predomínio do clero nâo sofria contestação.

Até então, a censura literária estava confiada ao Santo Ofício, ao Ordinário e ao Desembargo do Paço. A defesa da potestos régia era assegurada pela revisão do Desembargo. Globalmente, a prerrogativa que o Santo Ofício detinha na imposição dos índices expurgatórios determinava a orientação geral da censura, aspecto ademais reforçado pela vigilância privativa de outra instância judicial eclesiástica, o Ordinário ${ }^{25}$. Fora do alcance da malha censória ficavam apenas as obras escritas pelos sócios da Academia Real da História privilégio que premiava o interesse político-cultural da moderna agremiação instituída no Paço em 1720.

No que concerne à rede escolar, caracteristicamente mista e fortemente permeável à participação de agentes eclesiásticos, deve salientar-se que as congregações religiosas gozavam de autonomia na definição dos seus programas e objectivos formativos. Este facto ajuda a explicar a actualização. no século XVIII, dos métodos e das matérias ministradas nos cursos dirigidos

24 Franco Venturi, Settecento Riformatore, Vol. 4, t. I, I grandi stati dell'Occidente, Turim. Einaudi Editore, 1984, pp. 203 e ss.: Samuel J. Miller, Portugal and Rome c. 1748-1830. An aspect of the Catolic Enlightenment, Roma, Università Gregoriana Edrtnce, 1978; e José Sebastião da Silva Dias, Pombalismo e Projecto Politico, Sep. da Revista Cultura. História e Filosofia, vols. II e III, 1984.

25 Para os aspectos gerais do problema. Graça Almeida Rodrigues. Breve Históna da Censuro Literária em Portugal, Lisboa, Biblioteca Breve, 1980: Sobre as reformas introduzidas por Pombal, António Ferrão, A Censura Literário durante o Governo Pombolino, sep. da Academio das Sciêncios de Lisboo, Boletim da segunda classe, vol. XVII. 1923; e Maria Adelaide Salvador Marques, A Real Mesa Censória e a cultura nacional, sep. do Boletim da Biblioteca do Universıdade de Coumbro. vol. XXVI, 1964. 
pelos padres de S. Filipe de Neri e está também na origem de outras tentativas, bem sucedidas, de reorganização das classes e programas nas escolas afectas, primacialmente, à Terceira Ordem de $\mathrm{S}$. Francisco e à Ordem de S. Bento ${ }^{26}$. Num campo aberto à participação dos mais fortes, os jesuítas impunham-se sem esforço. Em Portugal dominavam a Universidade de Évora, definiam o cânone na habilitação aos estudos superiores em Coimbra, onde os seus mestres continuavam a pontuar, possuíam 34 colégios e 17 residências. No Brasil dirigiam 36 missões, 17 colégios e seminários e 25 residências ${ }^{27}$.

Neste horizonte, a unificação administrativa da censura e da instrução pública, instrumentum regni do maior alcance, viria a produzir um efeito demolidor na estrutura curialista da Igreja portuguesa. Do ponto de vista filosófico-jurídico, as prerrogativas majestáticas que sancionam a secularização daquelas instituições repetem as ideias desenvolvidas por António Pereira de Figueiredo acerca do primado da soberania régia sobre a jurisdição da Igreja 28 . O oratoriano português retoma, no essencial, as ideias de Justino Febrónio quanto à independência dos soberanos, à dignidade e autonomia dos bispos e à autoridade dos conclilos. "Ao definir o primado como uma função de carácter eclesial, Pereira de Figueiredo destruiu simultaneamente as bases em que se fizera assentar a soberania papal, tanto sobre os monarcas, como sobre os bispos. Explica-se, deste modo, que esta doutrina servisse de reforço do absolutismo dos príncipes e, ao mesmo tempo, à autonomia das igrejas locais. E explica-se também que, indirectamente, não fosse estranha ao regalismo, tanto na sua feição política, como na sua feição eclesiástica. Favorecendo a soberania dos príncipes e a autoridade dos bispos, implicitamente os unia contra o que se apresentava como intromissão abusiva dos respectivos direi-

26 José Sebastiâo da Silva Dias, Portugal e a Cultura Europeia, sep. de Biblos, vol. XXVIII. Coimbra, 1952, pp. 338-344; Jacques Marcadé, Frei Manuel do Cenóculo Vilas Boas évéque de Beja, archevéque d'Evora (1770-1814). Paris, Fundação Calouste Gulbenkian, 1978, pp. 33-49; e Luís A. de Oliveira Ramos, "Pombal e a Reforma dos Estudos Monásticos (O caso dos Beneditinos)". Revista de Históna das Ideios, O Marquês de Pombal e o seu Tempo, t. II. Coimbra, 1982. pp. $113-124$.

27 Kenneth Maxwell, ob. cit. p. 96.

28 Zilia Osório de Castro, "O Regalismo em Portugal. António Pereira de Figueiredo". in Cultura. História e Filosofia, vol. VI, 1987, pp. 357-4II e Cândido dos Santos, "António Pereira de Figueiredo. Pombal e a Aufklärung. Ensaio sobre o Regalismo e o Jansenismo em Portugal na $2^{a}$ metade do século XVIII", Revista de História das Ideias, O Marquês de Pombal e o seu Tempo, t. I. Coimbra. 1982, pp. 167-203. 
tos" 29. Mas, se as teses expendidas por este insigne teólogo do pombalismo, nomeadamente, no De Suprema Regnum (1760) e na Tentativa Teológica (1766) sancionavam inteiramente o controlo e a acção secularizadora do Estado no campo da educação e da produção cultural, na prática, a iniciativa de Pombal resultava da adaptação do modelo institucional austríaco da Bücherzensurcommission ${ }^{30}$. Esta comissão, dirigida por Gerhrard Van Switen, fora criada em Viena, oito anos antes da Real Mesa Censória, para combater o monopólio das escolas jesuítas, vigiar da actividade editorial e livreira e reformar o ensino público.

Conjunto à pessoa do rei, o tribunal da Mesa Censória, fundado em 1768, colocava-se, como assinala o seu regimento, acima das corporações educativas ${ }^{31}$. A actuação deste organismo, criado para favorecer o progresso das letras e das ciências, não só acentuou a perda de autonomia pedagógica das escolas públicas e particulares, como originou uma revisão global da função repressiva do Estado na vida intelectual do país. Sintomaticamente, no periodo mais fértil das reformas educativas pombalinas, ou seja, de 1768 a 1772, a imprensa periódica foi silenciada. Nenhum jornal nacional pôde ter voz activa sobre a orientação da política cultural do ministro de D. José 132 .

Mas vejamos como se harmonizam os critérios e as modalidades de imposição destas reformas. Como já salientámos, é no âmbito da reacção anti-jesuítica, mais concretamente, após a expulsão e confiscação dos bens da Companhia de Jesus, por carta régı de 19 de Janeiro de 1759, que surgem as primeiras medidas tendentes à reorganização do ensino ${ }^{33}$. Na sequência do alvará de 28 de Julho de 1759, que extingue as escolas jesuítas, é criado - lugar de Director Geral dos Estudos, com a atribuição de nomear para as mais importantes cidades do reino e vilas da província novos professores de

29 Zilia Osório de Castro, ob. cit., p. 403.

30 Samuel J. Miller, ob. cit. pp. 200-201.

31 Regimento do Real Meza Censoria, Impresso na Secretana de Estado. Anno de 1768 , tit. II. Cf. António Ferrão, ob. cit, p. 41.

32 Ana Cristina Araújo. Modalidades de leitura das Luzes no tempo de Pombal, sep. da Revista de Históno, vol. X, Porto, 1990, pp. 123-126.

33 Fortunato de Almeida, Histório da igreja em Portugal, $2^{\text {a }}$ ed. por Damiāo Peres, vol. III. Porto, Livraria Civilização, 1970, p. 121. Para uma visāo de conjunto da acçāo governativa de Pombal, vejam-se ainda: J. Lúcio de Azevedo, 0 Marquês de Pombal e a sua Época. $2^{\mathrm{a}}$ ed.. Lisboa. Clássica Editora, 1990, e Joaquim Veríssimo Serrāo, O Marquês de Pombal. O Homem. o Diplomata e o Estadista, Lısboa, Cámaras Municipais de Lisboa, Oeiras e Pombal, 1982. 
Gramática Latina, Grego e Retórica. Os diplomas em questão nada têm de conjuntural, na medida em que neles se enunciam as coordenadas ideológicas subjacentes ao vasto plano de reformas que levará mais de dez anos a ser executado ${ }^{34}$. Num primeiro momento, sobressai, nitidamente, a intenção de banir o poder paralelo dos jesurtas no campo do ensino e o propósito de impor uma certa uniformidade a todas as classes recém-criadas que ficavam. financeira e pedagogicamente, sob a alçada de um delegado do poder régio. Numa segunda fase, a Real Mesa Censória substitui a Directoria-Geral, extinta em 1771. O alvará de 4 de Junho desse ano, não só transfere a administração e direç̧ão das escolas menores do reino e domínios ultramarinos para a Mesa como the atribui a tutela do Colégio do Nobres, criado em 1761 e em funcionamento desde 1766 35. A possibilidade de "ordenação das Ciências Maiores" é então claramente enunciada, e a estrita dependência da corporação académica aos critérios de impressão e de licença de publicação definidos pela Mesa definitivamente firmada. Suporte da política educativa pombalina, este tribunal haveria, mais tarde, de travar os assomos de independência dos lentes da Universidade reformada que pretendiam ver subtraidos da alçada da censura régia os manuais redigidos para uso escolar. Em 1774, a Real Mesa Censória continuava a advertir que a liberdade de estampar os livros escritos para uso académico equivaleria a "abrir uma palestra para gladiadores futuros", entre lentes e censores, com notório prejuízo para ambas as partes ${ }^{36}$.

O dirigismo cultural pombalino avança gradativamente mantendo, todavia, os mesmos inimigos: os jesuítas e, com eles, todos os refractários à política regalista do ministério de D. José I. Com a expulsão do cardeal Acciaiuoli, em 1761, intensificaram-se os esforços diplomáticos em França, Espanha e junto da Cúria Romana para a dissolução da Companhia de Jesus. Internamente. e após sucessivas providências, com relevância para a lei de 4 de Maio de 1764. pela qual se declarava nulo e de nenhum efeito o breve pontifício da "nova

34 Sobre o assunto remetemos para o bem documentado trabalho de António Alberto Banha de Andrade. A Reforma Pombalina dos Estudos Secundários (1759-1771). Contribulçâo para a História do Pedagogia em Portugal, Coimbra, Por ordem da Universidade, 3 vols., 1981. $-1984$.

35. Rómulo de Carvalho. História da Fundaçõo do Colégıo Real dos Nobres de Lisboa (1761. -1772). Coimbra, Attântida, 1959.

36. Rui Manuel de Figueiredo Marcos, A Legisloção Pombolina. Alguns aspectos fundamentais. sep. do vol. XXXVIII do Suplemento ao Boletim da Faculdade de Direito da Universidade de Coim. bra, 1990.p. 43. 
confirmação do Instituto da Sociedade denominada de Jesus", assiste-se ao recrudescimento da campanha contra os padres inacianos. A chancelaria régia sustenta o libelo com documentos escritos ou produzidos sob a directa supervisão de Sebastião José de Carvalho e Melo e editados, em vários idiomas, com intuitos propagandísticos. Depois da Relação Abreviada, em que os jesuítas são, com grande escândalo, responsabilizados por graves actos de desobediência ${ }^{37}$, persiste-se na incriminação da acção missionária e educativa da ordem. Como ocorreu com outros textos do género, a Relação Abreviada apareceu traduzida em francês, italiano, alemão e inglês. Ao todo, cerca de vinte mil exemplares foram distribuídos e lançados no mercado europeu 38 .

Dez anos mais tarde, a Dedução Cronológica e Analítica, concebida em forma de memorial acusatório contra os jesuítas e a Cúria Romana, vincula o juízo disciplinador da legislação anticurialista de Pombal a uma racional interpretação histórica do direito português ${ }^{39}$. A "obra prima do Senhor marquês", no dizer do padre António Pereira de Figueiredo ${ }^{40}$, constitui o mais acabado ensaio de política regalista sobre matérias jurisdicionais consideradas exclusivas do poder régio. Ao historial das malévolas maquinaçōes atribuídas aos jesuítas, sustentado com documentação probatória, junta-se a refutação de alguns documentos pontifícios, nomeadamente, a "Bula da Ceia". A segunda parte da Dedução Cronológica e Analítica. vinda a lume exactamente no ano em que é criada a Real Mesa Censória, inclui ainda uma dissertação crítica sobre a soberania absoluta do Estado em matéria de censura intelectual. Doutrinariamente justificado, o anúncio da derrogação dos índices expurgató-

37 Publicada em Lisboa, em 1757, a Relação Abbreviada da Republica, que os Religiosos jesuitas das Provincias de Portugal, e Hespanha estabelecerão nos Dominios Ultramarinos das duas Monarchias, e do Guerra, que neles tem movido e sustentado contra os Exercitos Hespanhoes e Portuguezes: Formada pelos registos dos Secretarios dos dous Comissarios e Plenipotenciarios; e por outros Documentos authenticos, foi traduzida para francês pelo padre Norbert. mais conhecido por abade Platel. Sobre a ediçăo bilingue de 1757 e sobre a divulgação deste texto em França veja-se o que escreve Claude-Henri Frèches, "Pombal et la Compagnie de Jesus. La campagne de pamphlets", Revisto de História das IJeras. O Marquês de Pombal e o seu Tempo, t. I. Coimbra. 1982. pp. 300-302. Cf. Samuel J. Miller, ob. cit. pp. 107 e ss.. e Eduardo Brazão, "Pombal e os Jesuítas". Revista de História das Ideias, O Marquếs de Pombal e o seu Tempo, t. I. Coimbra, 1982. pp. 329-365.

38 Kenneth Maxwell, ob. cit., p. 20.

39 A Deducção Chronologica e Analytica.... dada à luz pelo doutor joseph de Seabro da Sylvo, foi redigida, com toda a probabilidade, pelo próprio Marquês de Pombal.

40 Cândido dos Santos, ob. cit., p. 188. 
rios marca o início da reforma legislativa censória, deixando antever, paralelamente, a transformação da estrutura funcional da Inquisição Portuguesa, convertida, poucos anos depois, em tribunal régio. Por ordem do Marquês de Pombal, a Dedução Cronológica e Analítica foi enviada a todas partes do reino e domínios ultramarinos. $\mathrm{O}$ padre Pereira de Figueiredo verteu-a em latim e, para maior divulgação, duas versões, uma em francês outra em italiano, garantiam, além fronteiras, a fama do déspota iluminado que a ideara ${ }^{41}$.

Outros dois monumentos anti-jesuŕticos esteiam as formulações regalistas dos conselheiros ministeriais de D. José I. São eles o Compêndio Histórico do Estado da Universidade de Coimbra, redigido no âmbito da Junta de Providência Literária, organismo tutelar da reforma da Universidade Coimbra, e o opúsculo intitulado Origem Infecta da Relaxação Moral dos Denominados Jesuítos, editado, anonimanente, pela Régia Oficina Tipográfica e impresso, tal como a obra anteriormente referida, em 1771. Aparentemente autónomos, os dois escritos mantêm entre si uma correspondência íntima. O "Sexto estrago ou Impedimento" que integra o capítulo II da II parte do Compéndio Histórico, é parcialmente reproduzido na Origem Infecta. Por outro lado, sabe-se que - Appendix para servir de suplemento ao mesmo capítulo é da lavra do padre António Pereira de Figueiredo. A participação deste oratoriano na redacção do Compêndio Histórico apresenta-se "despida de qualquer originalidade", dado que a referida passagem não passa de uma tradução adaptada da obra francesa: Assertions des Jésuites, publicada em Paris, em 1766, integrada na colecção com o título Recueil par ordre de dattes de tous les arrêts du Parlement de Paris ${ }^{42}$.

$\mathrm{Na}$ doutrina do Appendix, das vinte e duas atrocidades imputadas aos jesuítas sobressaem as condenações formuladas ao método peripatético, à Ética e à Metafísica de Aristóteles. Ao repúdio da escolástica, "fonte de ignorância e de corrupção", acresce a prolixa acusação de imoralidade e falta de observância dos preceitos evangélicos por parte dos padres inacianos. Como motivo de prova aponta-se o execrando erro do sigilismo, deliberadamente confundido com o abuso da confissão sacramental.

4 Samuel f. Miller, ob. cit, p. 212 e Ivan Teixeira, Mecenato Pombalino e Poesia Neoclássica. Basilio da Gama e a Poética do Encomio. São Paulo. Edusp. 1999. p. 65.

42 Cândido dos Santos, ob. cit., p.I88. 
Se, do ponto de vista jus-canónico, os argumentos essenciais da corrente jansenista, ou seja, o anti-romanismo e o anti-escolasticismo, eram amplamente contemplados na diatribe movida aos jesuítas, também a alusão explícita ao laxismo penitencial de certos confessores trazia subentendida a defesa de uma moral mais austera e rigorista. Neste aspecto, é possivel divisar alguns traços de proximidade entre os conselheiros de Pombal e os sequazes de Port-Royal. No entanto, a margem de ambiguidade das posições expressas pela Real Mesa Censória talvez pudesse ser concretizada desta forma: "the members of the Mesa were in fact inclined toward theological Jansenism, but opinions they express [...] should make it obvious that Portuguese theological position, although similar, was certainly not the same as of theological Jansenism nor was limited exclusivelely to questions concerning grace" 43 .

Sem pretendermos enfatizar a projecção dos ecos jansenistas na questão anti-jesuítica, não poderemos deixar de salientar que alguns dos mais influentes ideólogos do pombalismo revelam estar a par das grandes polémicas desencadeadas por este grupo no meio católico europeu. $O$ padre Pereira de Figueiredo mantém contactos epistolares com Gabriel Dupac Bellegarde, membro da igreja cismática de Utrech, e com o canonista valenciano Gregorio Mayáns y Siscar ${ }^{44}$. Troca ideias e sujeita a apreciação de frei Manuel do Cenáculo Vilas Boas, presidente da Real Mesa Censória e conselheiro da Junta de Providência Literária, as obras de Arnauld, de outros autores da "escola de Port-Royal" e "todos os bons e úteis papéis que o sábio francês [Dupac] continuamente [lhe] remete" 45 . Por seu turno, a legislação sobre eclesiásticos e as iniciativas da Junta de Providência Literária são motivo constante de notícia nas Nouvelles Ecclesiastiques, órgão oficial da facção jansenista francesa ${ }^{46}$. A outro nível, não passa também despercebida a aceitação do Catecismo de Montpellier, condenado em França, em 1721, por jansenismo, e introduzido em algumas dioceses do reino, nomeadamente em Évora, onde se distribuíram 4000 exemplares: Braga com 6000 exemplares vendidos, Porto que esgotou rapidamente uma

43 Samuel Miller, ob. cit., p. 212.

44 "Dupac read Pereira's Tentativa [and] continued to pour into Pereira's hands 'good books' from Utrech [...]. In 1768 he reopened the campaign to obtain recognition for Utrech from Rome by writing letters to Carvalho. Don Manuel de Roda, Spanish Minister at Hague. and to António Pereira", Samuel Miller, ob. cit., p. 251.

45 São a este respeito muito esclarecedoras as cartas dirigidas pelo padre Pereira de Figueiredo a frei Manuel do Cenáculo, B.P.E.. cod. CXI/2-1I.

46 Samuel Miller, ob. cit, p. 251. 
edição de 2000 exemplares; Coimbra e Lisboa e outros distritos episcopais para os quais não existem dados concretos ${ }^{47}$. Submetida à censura, em 1765 , a tradução portuguesa do catecismo, expurgada talvez das cinco proposições condenadas em França, obtém o parecer favorável de frei Manuel do Cenáculo, futuro bispo de Beja. E, em 1772, outra tradução da mesma obra volta novamente a ser objecto de licença de impressão 48 .

Em face do que ficou exposto, não é difícil perceber a importância instrumental de algumas proposiçōes jansenistas na querela religiosa e, consequentemente, o alcance que elas tiveram na política cultural pombalina, manifestamente permeável à teologia jansenista de Saci Lemaistre, de pseudónimo Royaumont, e de Johann Leusden, ensinada na Universidade de Coimbra após a reforma de 1772, e às sequelas radicais e tardias do jansenismo político de Gerhard van Swieten e de Paul Joseph von Riegger ${ }^{49}$. De qualquer modo, no âmbito da moral, a orientação jansenista não é unívoca e está longe de ter prevalecido sobre outras directrizes mais ortodoxas no campo da crença e arrojadas do ponto de vista filosófico.

\section{A Moral e a Politica}

Pensada como um dominio autónomo da teologia ${ }^{50}$, a Ética, tal como Vernei a define, é um exercício aberto ao livre entendimento que questiona

47 Estas informaçōes constam da correspondência enviada pelo padre e censor loăo Baptista de São Caetano a Dupac de Bellegande. cit in Samuel Miller, ob. cit.. p. 286. Para a diocese de Évora veja-se. Jacques Marcadé, Frei Manuel do Cenóculo Vilos Boos. Évéque de Beja. Archevéque d'Evora (1770-18/4). Paris Fund. Calouste Gulbenkian, 1978, p. 168.

48 Jacques Marcadé, ob. cit., p. 68.

49 José Antunes, Notas sobre o sentido ideológıco do reforma pombolina. A propósito de alguns dacumentos da imprensa da universidade de Coimbro, sep. da Revisto de História das ldeias, O Marqués de Pombal e o seu Tempo. t. II. Coimbra. 1982. pp. 167 e 174.

so $\mathrm{Na}$ carta undécima, Vernei coloca assim o problema: "Entendo por Ética aquela parte da Filosofia que mostra aos Homens a verdaderra felicidade, e regula as acçōes para o conseguir". E, mass adiante, diz: "Consistindo a Ética na colecção de preceitos que a luz de uma boa razão mostra serem necessários ao Homem para fazer aç̧ões honestas e também úteis à sociedade civil, pertence legitumamente ao Filósofo". Com esta reiterada afirmação procura refutar aqueles que se achavam persuadidos de que "a Ética somente pertence aos Teólogos a que chamam Moralistas ou Casuistas", Verdadeiro Método de Estudar, vol. III, pp. 254, 257 e 259. São idênticas as perspectivas de outros autores europeus. Cf. Michel Delon. "Morale", in Vicenzo Ferrone e Daniel Roche, ob. cit., p. 41-48. 
o modo se alcançar, em vida, a "suma felicidade" ou a "posse do um sumo bem". Na perspectiva da sua bem-aventurança natural, o indivíduo deveria interrogar-se sobre a "liberdode dos actos humanos", formular e formar um conceito de homem e, sob o governo da razăo, subordinar os mecanismos da sua natureza física e espiritual à legítima aspiração de perfectibilidade mora| 51 . Como se vê, a ordem do discurso de Vernei é comandada pela preocupação de demonstrar que a humanidade do homem não dispensa a ideação do bem e que a visão prospectiva do futuro, sendo acessível à razão, se apresenta como tradução secularizada da teleogia cristã.

Afastando-se neste ponto de Muratori, cuja obra qualifica de "difusa e inclinada muito para o sermão" 52 , Vernei, pelo primado que confere à Ética sobre a Metafísica e pela ligação que estabelece entre a ordem imanente da natureza e o uso racional da liberdade, aproxima-se de John Locke, "inglês famoso que tratou também do Direito Natural etc. com a sua costumada penetração e profundidade" 53 . Nos Some Thoughts concerning education (1693), a explícita defesa do papel da moral na transformação da sociedade objectivava a função normalizadora atribuída à educação. A conquista das virtudes morais, sendo acessível a todos os homens, independentemente da sua condição social, era todavia pensada em função de uma sociedade livre. Por este motivo, a leitura de Locke, sem deixar de inspirar a reflexão de Vernei -"há muita gente a quem não agrada por certas razões" - era preterida em favor da doutrina jusnaturalista de Grotius e de Puffendorf que conformava, em termos menos polémicos, o fundamento da acção justa ao estatuto do indivíduo submetido à soberania do príncipe.

Ora, se a essência da virtude se encontrava plasmada na ordem pré-estabelecida da Natureza, a Filosofia Moral tinha forçosamente de compreender a "jurisprudência natural" e a "prudência civil". A primeira, regida pelos imutáveis princípios da Natureza, devia familiarizar os indivíduos com as leis da razão universal, habilitando-o a um melhor relacionamento com Deus e com os

24 outros homens. A segunda, postulando a aplicação à causa pública, considerava as acções úteis ao reino, deslocando o comportamento dos súbditos para a esfera do direito positivo, da política e da economia. As noçōes de jus-

\footnotetext{
51 As expressōes em itálico sāo de Luís António Verney, ob. cit., vol. III, p. 288.

52 Luís António Verney, ob. cit.. vol. III. p. 295.

53 Luís António Verney, ob. cit. vol. Iil, p. 298.
} 
tiça, honestidade e decência, analisadas segundo o critério da utilidade pública, faziam prevalecer o interesse geral sobre a virtude particular, mas não a anulavam. Deste modo, a Filosofia Moral, aparecendo como disciplina propedêutica da ciência, conquistava o estatuto de saber indispensável à vida civil e ao bom governo da monarquia.

Na linha de pensamento de Vernei, o ensino da Filosofia Racional e Moral passa a ocupar um lugar de destaque em todas as Faculdades da Universidade de Coimbra, após a reforma de 1772. Sem comprometer a exposição imparcial dos seus fundamentos, aquela disciplina ajusta-se à orientação ecléctica subjacente à Filosofia do Direito. Aproveitando "judiciosamente" o melhor de cada escola, o eclectismo filosófico toma, neste campo, como autores de referência: Grotius, Puffendorf, Wollf, Heinécio, Martini e Muratori. A conciliação da matriz germânica da Aufklärung com os mais modernos desenvolvimentos do lluminismo católico italiano está, portanto, na origem de um corpo de doutrina alternativo à filosofia escolástica, considerada errónea e perigosa.

Fundamentando esta opção, os estatutos da Universidade de 1772 salientam os "fracos e mal seguros alicerces da Ética de Aristóteles", que colocam na origem do "probabilismo e do ateísmo" modernos. Tal asserção era sustentada pela impiedade do filósofo grego que, conforme se explicita, "nem reconheceu na Moral proposição alguma de eterna verdade nem admitiu lei alguma natural no seu verdadeiro sentido vindo consequentemente a estabelecer um Pirronismo Moral e fundando sobre ele todo o sistema da sua perniciosa moral" 54 .

À margem das escolas, mas ainda como forma de refutação da ética aristotélica, a exortação da filosofia atravessa o grande libelo público da época. Na pequena publicação intitulada Origem Infecta da Relaxação da Moral dos Denominados Jesuítos, a que já aludimos, surpreendemos esta sucinta e esclarecedora definição:

"A Filolosofia Moral é, sem controvérsia, a parte mais nobre da Filosofia; A Rainha das Disciplinas Filosóficas; o último termo e objecto de toda a Ciência da Razão.[...] É pois a directora dos pensamentos; a Norma das acções; a Disciplina dos costumes; o Orgão da Razão, pelo qual a natureza racional se explica e comunica com o homem; e a Arte de viver bem e felizmente. E tão relevantes são as vantagens que ela produz ao homem que, sendo-lhes relati-

54 Estatutos da Universidade, III, p. 90. 
vas todas as Disciplinas filosóficas, Ela é só a que mereceu e conseguiu a antonomásia de Ciência do Homem" 55 .

Sob a forma de manifesto filosófico, a propaganda anti-jesuítica transforma-se numa verdadeira arma de combate político. $O$ Estado gere a seu favor o conflito que desencadeia. Faz crer, através de verdades que sujeita ao crivo da demonstração racional, a evidência dos argumentos que utiliza, operação tanto mais arrojada quanto fundada em princípios que autorizam a mudança de direç̧ão de pensamentos e acções que, confinados à esfera da filosofia moral, possibilitariam e tornariam plausível a individuação da crítica. Em todo o caso, é por esta via que Pombal normaliza a cultura ilustrada, mobiliza a opinião pública, usando, arbitrariamente, noções e valores típicos das Luzes e conferindo inteligibilidade histórica a necessidades que firmam. objectivamente. o "monopólio da violência simbólica legítima" 56 do Estado. $E$ aqui reside um dos elementos mais caracteristicamente modernos da actuaÇão governativa do Marquês de Pombal. Através do controlo da imprensa e da escola, das artes e do urbanismo, o pombalismo multiplica procedimendos, monumentaliza acontecimentos e desenvolve motivos eficazes de imposição e de legitimação do poder ${ }^{57}$.

De facto, foi enorme, tanto no território nacional como por toda a Europa, o investimento realizado na divulgação das grandes obras e iniciativas lançadas pelo ministro de D. José I. Internamente, um dos momentos que melhor assinala o planeamento estratégico da propaganda pombalina é a criação, por alvará de 24 de Dezembro de 1768, da Impressão Régia. Ao "levantar uma Impressão útil ao público pelas suas produções", Pombal reafirmava o seu propósito de "animar as letras" e deixava subentendido o desígnio de ampliação de uma rede comunicacional eficaz e moderna, erguida a partir da chancelaria régia. A mesma orientação virá a ser adoptada na Universidade de Coimbra. com o estabelecimento, em 1772, de uma tipografia exclusiva-

55 Origem Infecto da Relaxaçōo da Maral dos Denominados jesuitas..., Lisboa, Regia Officina Typografica, 1771 , pp. 4, 7, e 8 .

s6 No sentido em que Pierre Bourdieu utiliza esta expressão, ou seja, quando refere o ocultamento subjacente à estratégia de imposiçâo de signos, representações e categorias de pensamento arbitrárias que, embora reconhecidas de forma lógica, preservam a ignorância daqueles que as incorporam, nelas acreditam e a elas se submetem, O Poder Simbólico. Lisboa. Difel, 1989.

57 Jorge Borges de Macedo, O Marquês de Pombal (1699-1782), Lisboa, Biblıteca Nacional. 1982. 
mente destinada à impressão dos novos manuais e diplomas legais respeitantes à corporação académica 58 .

E mesmo quando o confronto com a realidade aconselhava maior moderação, a margem de auto-convencimento acerca do êxito das medidas adoptadas era tal que D. Francisco de Lemos não se eximia, após o afastamento de Pombal, de reproduzir as elogiosas referências feitas pela imprensa estrangeira à reforma da Universidade: "tudo é dirigido ao bem geral da Sociedade, e ao fim que se deve propor em todas as Ciências; que é de conduzir os homens à virtude, unica e verdadeira felicidade. [...] Omito outros muitos lugares dos mesmos AA. [da Gazeta Eclesiástica de França]. Assim como das Actas de Leisik, os quais todos não só louvam a ordem do método e a solidez da doutrina; mas a religião e a piedade que respiram dos ditos estatutos" 59 . Outro confesso apologista de Pombal, o negociante Jacome Ratton, dava também o maior ênfase à herança cultural recebida - "Depois de tão sábias como providentes instituições que tiveram lugar durante o reinado do Senhor D. José, recebeu a Nação uma nova ilustração que hoje iguala a das nações mais polidas e iluminadas" 60 .

A matriz destas posições deve ser procurada na própria actuação de Sebastião José de Carvalho e Melo, pois é ele que fixa para a posteridade, no panegíico da sua administração, a imagem original da meticulosa construção que o irá perpetuar. Dirigindo-se ao monarca, diz: "os italianos e franceses não têm feito cerimónia de confessar muitas e repetidas vezes, respeitando e imitando as leis e resoluções de S. M., pedindo e invejando os estatutos da Universidade de Coimbra, a remessa de todos os escritos que se têm publicado e publicarem neste glorioso reinado" 61 . E, reportando-se expressamente à data da aclamação de D. José I e da sua ascensão à secretaria dos Negócios Estrangeiros e da Guerra, acrescenta, com manifesto exagero, "quando até o ano de 1750 era rara a pessoa que escrevesse uma carta com boa letra, há hoje a mesma raridade em encontrar quem escreva mal" 62 .

58 Em relação à tipografia da Universidade, o Marquês de Pombal recomendava a D. Francisco de Lemos que se devia estabelecer para a esta oficina "o mesmo que se achava estabelecido para a oficina regia", José Antunes, ob. cit., p. 150.

59. Franscisco de Lemos, ob. cit. p. 202

60 Jacome Ratton, Recordaçōes de ... sobre as ocorrrëncias do seu tempo, de Maıo de 1747 o Setembro de 1810.2.a ed., Coimbra. Imprensa da Universidade 1920, p. 166.

61 Cartas e outros obras selectas do Marquez de Pombal, $5^{a}$ ed.. Lisboa. Typographia de Costa Sanches. 1861, vol. I, p. 20.

62 Observoçōes Secretíssimas III, apud João Lúcio de Azevedo, ob. ct., p. 265. 


\section{Adiada reforma dos estudos superiores}

Em face do que ficou exposto, percebe-se o reduzido interesse de Sebastião José de Carvalho e Melo em reconhecer as falhas do sistema educativo que ideara e, para além disso, o deliberado silêncio a que vota outras propostas de reforma do ensino, anteriores e contemporâneas. Analisando - problema sob este prisma, facilmente se compreende que Luís António de Vernei e Ribeiro Sanches, apesar do afastamento que mantêm de Pombal, foram, em muitos aspectos, verdadeiros precursores das reformas educativas do século XVIII. Em função da precocidade e do arrojo das ideias expressas por Vernei no Verdadeiro Método de Estudar e das orientações traçadas por Ribeiro Sanches no Método para Aprender e Estudar a Medicina, nos Apontamentos para Fundar-se uma Universidade Real e nas Cartas sobre a Educação da Mocidade, deve admitir-se que a reformulação dos institutos escolares é uma ideia que vem do reinado de $D$. João $V$, que Pombal retoma, tardiamente, e à força, com alguns insucessos pelo meio, e sem o desenvolvimento esperado em áreas fundamentais, como, por exemplo, o acesso às bibliotecas de Lisboa, Coimbra e Évora, a regulamentação do cerimonial académico e a organização dos colégios da Universidade de Coimbra, isto apesar da propaganda em contrário promovida pelo seu ministério e pelos seus panegiristas.

$\mathrm{Na}$ verdade, a abertura às novas correntes científicas e filosóficas da Europa das Luzes conta, inicialmente, com o alto patrocínio dos mais esclarecidos ministros de D. João V. O mecenato régio, o academismo ilustrado do $4^{\circ}$ conde de Ericeira e o favorecimento que Alexandre de Gusmão, frei Gaspar da Encarnação, o Cardeal da Mota, Carbone e alguns membros do corpo diplomático, como D. Luís da Cunha, tributam à cultura racionalista contribuem, decisivamente, para cimentar o espírito do reformismo ilustrado em Portugal. Vernei que beneficia desta abertura confirma que "o bom gosto nas artes e nas ciências começou a introduzir-se em Portugal no feliz reinado

28 deste Augusto Monarca, o qual nisto tem ajudado mais o reino que todos os seus antecessores" 63 .

O cosmopolitismo cultural que então se faz sentir na capital atinge os cenáculos eruditos frequentados pela fidalguia. Na casa de Sebastião José de Carvalho e Melo nasce, com a magna protecção de seu tio, Doutor Paulo de

63 Luis António Verney, ob, cit.. vol. I. p. 20. 
Carvalho e Ataíde, a célebre Academia dos llustrados. A fama e o prestígio por si granjeados neste grémio erudito, mas também as boas relações que o seu tio arcipreste mantém com algumas figuras influentes do Paço, facilitam o ingresso do ambicioso futuro ministro na Academia Real da História. O lustre das letras e o espírito disciplinador do seu pensamento, mais do que o valimento intrínseco de sua linhagem, faziam-no notado. Antes mesmo das missões diplomáticas de Londres e de Viena de Áustria, onde colheu preciosos ensinamentos na arte da governação, já em 1736, se aventava a hipótese de Sebastião José de Carvalho e Melo vir a dirigir uma nova secretaria de Estado, exclusivamente dedicada aos negócios eclesiásticos e universitários 64 . Embora sem concretização, esta frustre proposta assinala a exacta cronologia de um problema sucessivamente adiado na sociedade portuguesa setecentista e, até talvez, uma linha de actuação programática na esfera conjunta da política religiosa e educativa, tal como mais tarde se veio a verificar.

Nesses idos anos trinta, "enquanto os políticos se informavam sobre - modo de levar as escolas a enveredarem por novos caminhos pedagógicos e científicos, os homens cultos faziam aumentar a pressão da novidade sobre a rotina" 65 . Ribeiro Sanches, achando-se então em Haia, escreveu, por "ordem e direcção de D. Luís da Cunha, um novo método de estudar que se devia introduzir na Universidade de Coimbra". Mais tarde, em missiva dirigida ao reitor Gaspar Saldanha, recordava que "aquele papel havia sido remetido à Corte, pelo dito embaixador, "no tempo em que o Cardeal da Mota era secretário de Estado"66. O documento em questão versava, essencialmente, sobre a reforma do ensino médico, como confessava Ribeiro Sanches, em 1735, a Sampaio Valadares, membro da Academia Real da História ${ }^{67}$. Sobre o mesmo assunto e por indicação do $4^{\circ}$ conde de Ericeira também o médico judeu Jacob de Castro Sarmento remetia de Londres alguns conselhos úteis 68 .

64 BNL, Pombalina, Cod. 8058. f. 240-243v. (Carta do Cardeal da Mota para D. João V. sobre a organização das secretarias de Estado).

65 J. S. Silva Dias. Portugal e a Cultura Europeia.... p. 373.

66 BNM, ms, 18371, fl. 276-276v., cit, in Ana Cristina Araujjo, llustruççõo, Pedagogia e Ciência em António Nunes Ribeiro Sanches, sep. da Revista de História dos Ideios, vol, 6. 1984, p. 378.

67 Cit. in David Willense, Antónı Nunes Ribeiro Sonches - Éleve de Boerhoave et son importonce pour la Russie, Sep. de Janus, vol.VI, Leiden, E. J. Brill, 1966, pp. 7-8.

68 Embora ocultando o contributo de Ribeiro Sanches, os membros da Junta de Providência Literária salientam o envolvimento de Jacob de Castro Sarmento na tentativa de reforma do ensino médico ensaiada por D. João V. "Conhecendo o mesmo Monarca a deca- 
Mas não era só a modernização do ensino médico e cientííco que estava na ordem do dia. No entendimento de $D$. João $V$ a renovação dos cursos universitários passava pela criação de uma biblioteca actualizada nos mais variados domínios do saber e, portanto, bem provida de livros. O mecenato régio era mais intelectual e estético do que material, dado que a Universidade ficava vinculada ao financiamento de uma obra, cujo esplendor não se destinava apenas a deslumbrar o olhar, mas a transformar os hábitos de estudo e os conteúdos dos cursos ministrados na alma mater. A Biblioteca seria portanto a mola da reforma das Faculdades. É isso que se depreende deste passo de uma carta do Cardeal da Mota a D. Luís da Cunha, datada de I de Setembro de 1729, "El Rey meu S.or reconhecendo quanto he indecoroza ao cred." da Un.e de Coimbra a falta de hũa Livraria publica, foi servido mandar construir hũa grande Caza para este emprego, a qual se acha inteiram.te acabada, q. to ao material; mas q. to ao formal tanto no principio. q. apenas tem hū pequeno corpo de AA. juristas" 69. Para prover a magnificente construção do Paço das Escolas, faz-se uma primeira encomenda de "livros de Filosofia e de Medecina, especialmente dos sistemas modernos" 70 . Esta e as remessas seguintes, adquiridas por intermédio de D. Luis da Cunha, incluem, a conselho de Ribeiro Sanches, títulos escolhidos pelo "método que se tomou na Universidade de Leyde" 71 . Desta forma, o diplomata português em Haia e o médico cristão-novo que então frequentava, sob a direcção de Boerhaave, a famosa Universidade de Leide envolvem-se activamente na pré-reforma que atinge o velho baluarte universitário português. Perante tantos e tão úteis conselhos, o cardeal da Mota esclarece, definitivamente, os seus interlocutores das reais

dencia, em que se achava a Medicina; e quanto concorrena para seu restabelecimento o magis. tério do famoso Boerhave [ ...] mandou convidalio com a promessa de huma larga pensão facto que a documentação não confirma -.....] Mandou o mesmo Augustissimo Senhor consultar em Inglaterra Jacob de Castro Sarmento que [...] referio pelos Doutores que consultou: Primo, que se deviam traduzir as Obras Originaes do illustre Baconio [...]Secundo, que se man. dassem Estudantes fóra do Reino fazerem-se peritos nas mesmas Sciencias". E mais adiante acrescenta-se: - "A estes projectos de refórma succedêram outros, que os Jesuitas procuráram tambem desconcertar", Compéndio Histónco..., pp. 345 e 348.

69 BAC, Série Azul, ms. 592, n 368. Deve-se a J. S. da Silva Dias, a primeira indicação sobre o valor e importância desta correspondência, Portugal e a Cultura Europeia.... p. 476.

to BAC. Série Azul. ms. 592, $n^{\circ}$ 408. Carta do Cardeal da Mota a D. Luís da Cunha de 12 de Outubro de 1729

71 BAC. Série Azul, ms. 592, n 399. Carta do Cardeal da Mota a D. Luis da Cunha de 2 de Agosto de 1730. 
intenções de D. João V: "El Rey meu Sr. aprova inteiram.te tudo q. to V. Ex. tem obrado nelle [...]. pois he igualm.te precizo, e importante q. se emmende o methodo de estudo da nossa Universidade, não só no que respeita à medecina, mas ainda q to às mais faculdades" 72 . Mas, a resistência da corporação académica à mudança e a falta de firmeza do reitor reformador. Francisco Carneiro Figueiroa, dificultavam a adopção de medidas concretas. Por isso, pouco tempo depois, o cardeal da Mota voltava à carga:

"Recebi a cópia da ã escreveu a V. Ex $x^{a}$ Ant $^{\circ}$ Ribr ${ }^{\circ}$ Sanches, a qual li com particular gosto, porq. sem dúvida he hũ papel cheio de erudição, de nas muito vastas, e exquizitas, e de excellentes arbitrios, p. $^{\text {a }}$ desterrar a ignor. ${ }^{\mathrm{a}}$ em q̃. estamos, no que respeita à Medecina, sobre q̃. discorre o autor com tanta propriedade q̃. bem mostra possuir hũa inteira not. ${ }^{a}$ do q̃. se passa no nosso Paiz, e nos estranhos. Pela minha parte entendo q̃. não só he conveniente, mas preciso executarse tudo o q̃. se propõe no dito papel e tambem creyo q̃. não custará isto tanto trabalho q. to havera em venser a repugnancia e as contradiçoens de todos aquelles ã. sem mais exame aborrecem qualquer $n$.de só porq. o he; contudo não perco a esperança de fazer algum serviço ao público nesta import te materia [ ...] mas nunca fiarei o dito papel dos Lentes da Universid.e de Coimbra, sem embargoo de lho haver prometido, porq. fazerlhes esta confiança, em lugar de util seria mui prejudicial ao intento" 73 .

Em 1733 era já notório o desalento do ministro de D. João V. Os livros que chegavam à biblioteca eram um peso morto na Universidade, por isso dizia, em desabono dos lentes, "se os que se esperão [de Jurisprudência e Teologia] tiverem tanto uzo, como athe agora tem os Medecina moderna, que ja se achão naquella livraria, nenhûa falta farão" 74 . Mesmo assim, a Universidade, contra a vontade dos seus mestres e a indiferença da corporação estudantil, ficara dotada das armas que a haveriam de transformar - os livros dos autores dos "mais modernos sistemas filosóficos". Dos róis de aquisição e pagamento de encomendas para a biblioteca constam obras de Grotius, Puffendorf, Wollf, Heinecio, Mabillon, Tomasio, Fleury, Quesnel, John Locke, Herbelot, Boerhaave. Gassendi, Descartes. Kepler. Galileu. Torricelli, Jacob S'Gravesande.

\footnotetext{
72 idem, ibidem.

73 BAC, Série Azul, ms. 592, n 395. Carta do cardeal da Mota a D. Luis da Cunha del7 de Outubro de 1730.

74 BAC, Série Azul. ms. 592, $n^{\circ}$ 388. Carta do cardeal da Mota a D. Luís da Cunha de 29 de janeiro de 1733.
} 
Bayle, Capasso, traduções francesas de Petrus Van Musschenbroek e Jan Van Musschenbroek, inúmeros dicionários temáticos e enciclopédicos, repertórios bibliográficos especializados, Actas de Academias Científicas Europeias, entre muitas outras espécies de idêntico interesse e actualidade ${ }^{75}$.

Neste capítulo pouco se inovou cinquenta anos depois. Em boa parte, os manuais que a Junta de Providência Literária adoptou para as Faculdades reformadas em 1772 achavam-se, na sua grande maioria, há muito arrumados nas estantes de vistosa chinoiserie que ornavam a majestática e actualizada livraria pública do Paço das Escolas. Não admira portanto que o corpo de conselheiros do Marquês de Pombal para as reformas do ensino tenha sido maioritariamente constituído por homens de formação académica, herdeiros espúrios da escola que criticavam. Aliás, a base da elite do poder do Pombalismo - exceptuando o reduzido escol de grandes mercadores que enriqueceram à custa da protecção do Estado - é essencialmente constituída por eclesiásticos e magistrados que beneficiaram da ilustração joanina, do cosmopolitismo cultural da época dourada da monarquia e do galicanismo atribiliário do reinado do Fidelíssimo.

\section{A criação de uma elite esclarecida: fracassos e armadilhas}

Como bem salienta Kenneth Maxwell, "the effort made by Pombal to create an enlightened generation of bureaucrats and officials was to benefit his successors, but in his own administration he relied on a very small group of collaborators." 76 . De facto, "os varões mais sábios e autorizados do reino", chamados a colaborar nas reformas do ensino, desempenharam as suas funções de conselho em regime de notória acumulação de cargos. Na Real Mesa Censória presidida, inicialmente, pelo cardeal D. João Cosme da Cunha, encontramos como deputados ordinários: o oratoriano António Pereira de

75 BAC, Série Azul, ms, 591, n’s 108, 116, 126 e ms, 592, ns 368, 390. 394. 398. No entanto, só uma comparação dos catálogos de obras escolhidas e dos respectivos verbetes de entrada permitirá apurar se houve restriçōes ou censura nas aquisições efectrvamente realizadas. Para além disso, é de admitir que outros canais tenham sido utilizados para o apetrechamento da Biblioteca Joanina. A problemática avançada e as suspeitas existentes tornam ungente a elaboraçâo de um estudo sistemático sobre o assunto.

76 Kenneth Maxwell, ob. cit., p. 106. 
Figueiredo; o beneditino frei João Baptista de São Caetano; o franciscano da Terceira Ordem, frei Manuel do Cenáculo; frei Luís de Monte Carmelo, da Reforma de Santa Teresa de Jesus; o doutor António Manuel Nogueira de Abreu, juiz dos Feitos da Corod; o doutor Francisco de Lemos de Faria. juiz geral das três Ordens Militares; e o doutor João Pereira Ramos, desembargador da Relação do Porto.

Para a Junta de Providência Literária, presidida por Sebastião José de Carvalho e Melo, os conselheiros escolhidos continuavam a ser o cardeal da Cunha, um familiar dos Távoras fiel a Pombal, frei Manuel do Cenáculo, censor e preceptor do Príncipe D. José; e os irmãos João Pereira Ramos de Azeredo Coutinho e D. Francisco de Lemos Faria Pereira Coutinho, este ocupando já o lugar de Reitor Reformador da Universidade. Para além destas personalidades que transitavam directamente da Real Mesa Censória para a Comissão encarregada de preparar a Reforma da Universidade, a Junta integrava ainda: os desembargadores do Paço, José Ricalde Pereira de Castro e José Seabra da Silva; o doutor Francisco António Marques Geraldes, deputado da Mesa da Consciência e Ordens; e o doutor Manuel Pereira da Silva, desembargador da Casa da Suplicação.

À excepção dos mecanismos institucionais que garantiam a dignificação honorífica dos detentores de grandes fortunas, função acometida à Junta do Comércio, (1756) e dos meios postos à disposição da classe mercantil para a obtenção de conhecimentos úteis - a Aula do Comércio (1759) - que, em conjunto, colocaram na órbita do Pombalismo poderosos apoiantes 77 , Sebastião José de Carvalho e Melo não consegue formar, apesar do afinco posto na educação das gerações mais novas, uma elite alargada e ideologicamente consistente em torno do seu modelo de Despotismo Esclarecido.

O Colégio dos Nobres, instituído por carta régia de 7 de Março de 1761 e aberto cinco anos depois, não passava de uma solução intermédia no processo de constituição de uma elite do poder. O projecto de dotar o país de uma instituição similar à Escola Militar de Paris é veiculada, em primeira mão, no ano de 1715, pelo embaixador D. Luís da Câmara. Vernei que lastima a ignorância e o conservadorismo da nobreza nacional, discutindo mesmo os falsos pergaminhos de certas familias de remota origem, acentua também

77 José-Augusto França, "Burguesia pombalina, nobreza mariana, fidalguia liberal", in Pornbol Revisitado. (coord. Maria Helena Carvalho Santos). vol. I, Lisboa. Estampa, 1984. pp. 19-33. 
a necessidade de correç̧ão dos costumes da fidalguia. De forma mais concreta, Martinho de Mendonça de Pina e Proença precisa os moldes em que deveria assentar a educação desses varões de nascimento ilustre. $O$ seu programa de instrução destinava-se a tornar o trato dos meninos mais amigável e civilizado e a inclinar o ânimo destes para a aprendizagem da filosofia e da ciência, de acordo com os progressos do século. Mais tarde, Ribeiro Sanches não só insiste na necessidade de se fixarem limites aos privilégios secularmente acordados à nobreza, responsabilizada pelo "descalabro moral da nação", como retoma, com novos fundamentos, a ideia de criação de uma instituição destinada à instrução dos filhos das melhores familias. Nas Cortos sobre a Educação da Mocidade, colige programas e fornece indicações sobre o modo de funcionamento dos colégios militares de cadetes instituídos na Rússia, na Áustria, em França, na Dinamarca, na Suécia e na Prússia. Em seu entender, a domesticação cultural da fidalguia e seu aproveitamento funcional por parte do Estado deveria, em primeiro lugar, reverter a favor da modernização do Exército e da Marinha. Apostando num programa de instrução adequado às exigências da governação. Ribeiro Sanches preconiza não tanto a dignificação dos cargos mas a qualificação dos serviços prestados pela nobreza nesses ramos fundamentais da administração ${ }^{78}$. Esta perspectiva, sabe-se hoje, encontrava eco no correio diplomático expedido para a Secretaria de Estado dos Negócios Estrangeiros e da Guerra. Em 1752, Ambrósio de Andrade e Castro, nosso embaixador em Viena de Áustria, informava Sebastião José de Carvalho e Melo que "os tres colegios da instiuissão de S. M. a Imp. $R^{3}$ vão produzindo a utilidade que se imaginou na sua creassão. Dentro em poucos anos os Estados hereditarios estarão cheyos de fidalgos mossos bem instroidos, e as tropas de oficais cientes. No colegio Theresiano tenho assistido a algûns exames a que fuy convidado, e afirmo a V. Ex me assombra o ver rapazes tão fundamentalmente instroidos nas bellas letras, e nas Mathematicas. No colegio dos Engenheyros também ouso se avansão 34 muito. Eu tenho as instituissoens se $\mathrm{V}$. Ex $\mathrm{x}^{\mathrm{a}}$ as quiser remeterey" 79.

78 A sucinta exposiçâo destes programas é fornecida por Rómulo de Carvalho, ob. cit., pp. 15-24. Merece todavia revisão a parte consagrada à análise do pensamento de Ribeiro Sanches, como salienta António Rosa Mendes, Ribeiro Sanches e o Marquess de Pombal Intelectuais e Poder no Absolutismo Esclorecido, Cascais, Patrimonia, 1998.

79 ANTT, Ministério dos Negócıos Estrangeiros, Legação da Áustria, caixa A, 1752. 
Apesar da falta de quadros e de meios técnicos para a modernização do exército português - situação particularmente sentida em vésperas da invasão franco-espanhola de 1762 - despreza-se a hipótese de consolidação técnico-profissional dos altos postos da hierarquia militar, cujo exercício requeria ou dava nobreza. Em detrimento de um colégio de cadetes, opta-se por um tipo de instituição hibrida. A utilidade social e política da nova instituição decorria do seu programa de estudos, basicamente centrado em disciplinas de humanidades, ciências, línguas estrangeiras e na prática de algumas actividades físicas. como a esgrima e a dança. Em termos orgânicos, a escola-internato então criada transpunha para o micro-cosmos cortesão as regras de civilidade e de boas maneiras que vigoravam na Europa civilizada. Mas, ao mesmo tempo que ocupava, de modo dignificante, a primeira juventude do reino, alargava a sua competência cultural, quer através da prática das ciências experimentais, quer por meio do acesso à leitura, em vários idiomas, de autores modernos.

Com um orçamento fabuloso, o colégio suporta as despesas feitas com a contratação de um vasto escol de professores estrangeiros e custeia a aquisição de máquinas e instrumentos para o seu gabinete de Física, considerado um dos melhores da Europa. Reunindo, à partida, condições atractivas para o recrutamento de alunos, a nova fundação, inicialmente pensada para albergar cem porcionistas, não consegue, ao longo do período que vai de 1766 a 1772 , ter mais do que 34 colegiais internos ${ }^{80}$. Durante anos sucessivos não se registam primeiras matrículas. As casas titulares resistem à ideia de colocar os seus filhos no Colégio dos Nobres. E os poucos que assim procedem arrependem-se. Ao segundo ano de frequência, são mais moços-fidalgos que saem do que aqueles que entram no internato do alto da Cotovia. Tem-se salientado a falta de disciplina interna e a deficiente organização dos cursos como motivos de fracasso desta instituição ${ }^{81}$. Independentemente destes aspectos, pensamos que a razão de fundo é outra. A Nobreza não se revê na escola nobiliárquica pombalina. As condições de candidatura dos colegiais omitiam aspectos considerados fundamentais à estratégia de conservação das casas, isto é, não distinguiam descendência legítima e bastarda, nem discriminavam primogénitos de segundogénitos, tornando assim pouco claro o esquema de recompensas no agenciamento de carreiras para os diferentes

\footnotetext{
80 Rómulo de Carvalho, ob. cit. pp. 180 e ss.

81 Rómulo de Carvalho, ob. cit. pp. 143 e ss.
} 
descendentes das familias nobres ${ }^{82}$. Por isso, e contra as normas de recrutamento fixadas pelos Estatutos, meninos de nascimento obscuro, oriundos de familias ambiciosas e abastadas. passam a ocupar os lugares deixados vagos pela fidalguia ${ }^{83}$. No meio de tais vicissitudes, Pombal suspende em 1772 o ensino das ciências no Colégio dos Nobres e transfere os instrumentos do laboratório que equipavam as classes de Física e de Matemática para a Universidade de Coimbra.

Na Série Chronologica dos Factos e Ordens relativos à disciplina do Real Colegio dos Nobres, redigida por frei Manuel do Cenáculo, em 177684, deparamos com um acervo largo de reflexões que confirmam o nosso ponto de vista. Pese embora o facto de aí se considerarem "idiotas" os colegiais "refugiados da calamidade que padece a nobreza", a incultura e a arrogância, - como se explicita mais adiante - o que verdadeiramente preocupa o Presidente da Real Mesa Censória não é a indisciplina interna, prevenida e punida asperamente, nem tão pouco as "maximas perniciosas em moral e política entre professores e colegiais", pois, à excepção de um caso conhecido e perfeitamente identificado, não havia razões para alarme. $O$ que seriamente embaraçava a aç̧ão da Mesa era a inquietação das familias titulares e as prevaricações externas movidas, em conluio, contra o Colégio dos Nobres. Tanto mais que havia, como se reconhece, instituições concorrentes, os "Colégios de S. Pedro e de S. Paulo" de Coimbra, e classes particulares ministradas por professores sem escrúpulos, mas com boas relações com as citadas corporações coimbrãs, que "faziam as delicias de muitos fidalgos da Corte" 85 .

Votado uma vez mais ao fracasso, o processo de renovação ensaiado no Colégio dos Nobres será aprofundado, com outro enquadramento institucional e de forma bem diversa na Universidade de Coimbra ${ }^{86}$. O primado con-

82 Sobre os modelos educacionais da nobreza titulada veja-se. Nuno Gonçalo Monteiro. O Crepúsculo dos Grandes (1750-1832), Lisboa, IN-CM. 1998, pp. 519-528.

83 Veja-se a relação dos colegiais, para o periodo de 1766 a 1772, em Rómulo de Carvatho, ob. cit., pp. 179-190.

84 ANTT. Ministério do Reino, Assuntos Eclesiásticos, maço 596, caixa 697.

85 Idem, ibidem

86 No alvará régio de 10 de Novembro de 1772 que extıngue o ensino cientifico no Colégio dos Nobres esclarece-se que "as totais ruinas, em que na Universidade de Coimbra achei sepultadas as Sciencias" levaram à criação do dito colégio para "que Eu antecipasse pelo menos a alguns dos Meus Subditos, os conhecimentos das Sciencias Mathematicas, que fundam os solidos Principios para as Instruç̧ões das outras Disciplinas", orientação que persiste na Univer- 
ferido ao conhecimento racional e científico, evidenciado nos programas dos cursos das recém-criadas Faculdades de Matemática e Filosofia e imposto, também, à Faculdade de Medicina exigiu a instalação de equipamentos técnico-experimentais adequados: o laboratório de Física, o jardim botânico, o observatório astronómico, o teatro anatómico e o despensatório farmacêutico. Nestes espaços, a função do magistério universitário muda substancialmente. Os professores das novas Faculdades deviam ser, ao mesmo tempo, mestres e inventores, atributos expressamente requeridos pelo reitor reformador D. Francisco de Lemos. Paralelamente, nas restantes Faculdades. as transformações motivadas pelas orientações pedagógico-doutrinárias consagradas nos Estatutos de 1772 conferiam uma dimensão marcadamente cívica ao trabalho dos académicos. A missão educativa de lentes e opositores passa então a ser aferida pelo estatuto atribuído ao ensino superior. no quadro de um estreito compromisso ideológico-político da Academia com o Absolutismo Esclarecido.

\section{A Universidade - Um corpo formado no seio do Estado}

De facto, um dos traços mais característicos da reforma pombalina do ensino superior reside na reformulaçãa do conceito de Universidade. Como claramente explicitava D. Francisco de Lemos:

"Não se deve olhar para a Universidade como hum Corpo isolado, e concentrado em si mesmo, como ordinariamente se faz; mas sim como hum Corpo formodo no seio do Estado, por meio de Sabios, que cria, difundir a Luz da Sabedoria por todas as partes da Monarchia; para animar, e vivificar todos os Ramos da Administração Publica; e para promover a felicidade dos homens; illustrando os seus Espiritos com as verdadeiras noçoens do justo. do honesto. do util e do decoro; formando os seus coraçoens na pratica das Virtudes sociaes e Cristhans; e inspirando-thes Sentimentos de Humanidade, de Religião, de Probidade, de Honra, e de Zelo pelo Bem Publico.

Quanto mais se analisa esta ideia, mais relaçoens se descobrem entre a Universidade e o Estado; mais se conhece a mutua dependencia que tem

sidade reformada. Rómulo de Carvalho. "As Ciências Exactas no Tempo de Pombal". Broténo, Culura e informação, vol. 114- ns 5-6, 1982, pp. 575-589. 
estes dois Corpos um do outro, e que as Sciencias não podem florecer na Universidade, sem que o Estado floreça, se melhore e se aperfeiçoe" 87 .

A reiterada afirmação de subordinação da corporação académica ao poder político é compaginável com a tutela ideológica do Estado sobre educação e, no caso da Universidade, com a legitimidade própria que the advém da tradição. Como no passado, o Estado avoca a si a revisão dos Estatutos da corporação universitária e, através deles, define o processo de selecção, transmissão e aplicação de saberes considerados úteis à sociedade. Todavia, a limitação da autonomia universitária, tradicionalmente admitida na constituição do corpo docente, na designação do reitor, na revisão dos conteúdos de ensino e derrogação de Estatutos, é levada mais longe por Pombal. A orgânica interna da instituição é modernizada, o sistema de remuneraçōes dos professores simplificado, a ordem das Faculdades torna-se potencialmente conflitiva ${ }^{88}$ e, sobretudo, a exigência de envolvimento de alunos e mestres num processo de renovação que transcende a própria academia, prefiguram uma linha de compromisso político nunca antes formulada de forma tão nítida e inequívoca. É claro que neste quadro teriam que ser mais fortes as motivações e as expectativas daqueles que passariam a frequentá-la.

Antes da expulsão dos jesurtas, o diploma universitário não conferia propriamente uma condição técnica ao bacharel, nalguns casos funcionava apenas como passaporte para um estatuto de superioridade social que ratificava ou não a condição anterior ao ingresso na Universidade. A partir da reforma pombalina, o mérito associado à competência específica dos graduados sobrepõe-se ao princípio de diferenciação estamental, sem contudo com ele colidir. $O$ exemplo mais flagrante disso encontra-se na disposição estatutária que cria carreiras de prestígio para "os matemáticos" e que tributa a este sábios o privilégio de admissão na fidalguia. Num dos parágrafos do texto dos Estatutos dos Cursos de Sciencias Naturaes e Filosoficas pode ler-se: - "Haverei a todos os Fidalgos da minha Casa, por serviço vivo na Campanha, todo o tempo, que cursarem a Mathematica na 38 Universidade. $O$ qual quero que lhes sirva para serem preferidos nos Póstos, que costumam ser despachados em Pessoas da sua qualidade" 89.

87 Francisco de Lemos, ob. cit., p. 232, (sublinhado nosso).

88 Luís Reis Torgal, "Universidade. Ciência e 'Conflito de Faculdades' no lluminismo e nos Primórdios do Liberalismo Português". in Cloustros Y Estudiantes, Valencia, 1989. pp. 291-299.

89 Estatutos da Universidade De Coimbra (1772). III, Coimbra, Por ordem da Universidade. 1972. p. 149. 
A valorização social do saber exigia que se criassem novas profissões e que se escolhessem os mais capazes e os melhor habilitados para as já existentes, o que implicava "uma renovação em todos os objectos do governo do Estado", conforme salientava D. Francisco de Lemos 90 . Segundo esta lógica, cabia ao soberano mandar "que nos empregos, lugares e póstos das diferentes profissões, que na Universidade se ensinam, ninguém pudesse ser provido que não fosse ao menos bacharel formado nas respectivas Escolas" 91 . $\mathrm{O}$ acento dado à componente técnica e profissional diminuía, sem pôr em causa, os pressupostos básicos de conservação de uma sociedade regida pela antiguidade da honra e do privilégio. Na prática, o moderno propósito de distinção de novos talentos vinha apenas tornar mais conflitivas as relações internas no seio da nobreza. Este desequilibrio era, todavia, contrabalançado pela preferência que as melhores familias do reino continuaram a ter no agenciamento de carreiras para os seus descendentes. Para isso serviam as corporações subalternas da Universidade, nomeadamente os colégios de S. Pedro, de S. Paulo e das Ordens Militares que, no essencial, permaneceram intocados.

E se Pombal não teve coragem política para modificar a orgânica interna e a finalidade de tais institutos, a verdade é que deles se serviu para promover os seus apaniguados. Em 23 Setembro de 1772, impõe ao colégio de S. Pedro o provimento de 10 colegiaturas com indicação explícita dos nomes que as deveriam ocupar e com a ressalva de inibição das respectivas inquirições, de vita et moribus e de sangue ${ }^{92}$. Para os lugares de porcionistas observam-se também condições excepcionais de provimento. A aceitação de D. Francisco de Castro, filho do conde de Resende, é admitida sem deligências, porque o candidato "era de casa tam ilustre e sobrinho do cardeal da Cunha"93. Em 14 de Junho de 1775, o colégio recebe uma Provisão do Marquês de Pombal onde se faz mercê de "uma beca de colegial porcionista [...] a favor de D. Jorge de Menezes" 94.

90 Idem, ibidem, p. 234.

91 Idern, ibidem, p. 234.

92 AUC, Livro das Colegiaturas 6, fl, 57, capela de 23 de Setembro de 1772. Veja-se a relação discriminada dos colegiais em Cristovão Correia de Oliveira. O Saber e Poder: $O$ Colégio Real de S. Pedro da Universidade de Coimbra (1700-1834), Coimbra, dissertação de mestrado. 1996.

93 AUC, Livro das Colegiaturas 6, fl. 58r-v, capela de 18 de Novembro de 1772.

94 AUC, Livro das Colegiaturas 6, fl.63, capela de 14 de Junho de 1772. 
Estes e outros casos mostram que a mercê régia é utilizada para esvaziar a autonomia da corporação colegial, que quase perde o controlo da disposição de lugares afectos às respectivas colegiaturas. De resto, a análise dos percursos de carreira de colegiais e porcionistas de S. Pedro permite verificar que as grandes familias não abdicam deste poderoso trampolim para promoverem os seus secundogénitos, socorrendo-se, cada vez mais, do patronato régio 95. Por esta via, a secularização da vida académica, sem comprometer a estratégia de perpetuação e renovação da elite nobiliárquica, acabará por arrastar para o lado dos eleitos do poder novos nomes e novas competências que, de forma contraditória. confiarão cada vez menos neste mecanismo de perpetuação de poder na sociedade portuguesa. 